\title{
Metabarcoding advances for ecology and biogeography of Neotropical protists: what do we know, where do we go?
}

\author{
${\text { Camila Duarte Ritter }{ }^{1,2 *}{ }^{\circledR} \text {, Arielli Fabrício Machado }}^{3 \oplus}$, Karine Felix Ribeiro $^{3 @}$ \& Micah Dunthorn ${ }^{1,4,5}$ \\ ${ }^{1}$ University of Duisburg-Essen, Faculty of Biology, Eukaryotic Microbiology, Universitätsstrasse 5, D-45141 \\ Essen, Germany. \\ ${ }^{2}$ Universidade Federal do Paraná, Departamento de Zootecnia, Grupo Integrado de Aquicultura e Estudos \\ Ambientais, Rua dos Funcionários, 1540, Juvevê, 80035-050, Curitiba, PR, Brasil. \\ ${ }^{3}$ Universidade Federal do Rio Grande do Sul, Instituto de Biociências, Programa de Pós-Graduação em \\ Ecologia, Rua Bento Gonçalves, 9500, 91501-970, Porto Alegre, RS, Brasil. \\ ${ }^{4}$ University of Duisburg-Essen, Centre for Water and Environmental Research (ZWU), D-45141 Essen, Germany \\ ${ }^{5}$ University of Oslo, Natural History Museum, N-0562 Oslo, Norway. \\ *Corresponding author: kmicaduarte@gmail.com
}

RITTER, C.D., MACHADO, A.F., RIBEIRO, K.F., DUNTHORN, M. Metabarcoding advances for ecology and biogeography of Neotropical protists: what do we know, where do we go? Biota Neotropica 21(4): e20211214. https://doi.org/10.1590/1676-0611-BN-2021-1214

\begin{abstract}
The Neotropics is one of the most diverse regions of the globe in terms of plants and animal species. Regarding the microbial world, however, little is known about the diversity and biogeography patterns of microorganisms in the Neotropics. The biogeography of several microbial taxonomic groups is still missing and/or incomplete, such as the protists. Despite the hard taxonomic identification of protists, the advance of molecular techniques (e.g., metabarcoding) have allowed to better explore the distribution of several protistan groups. Our goal here was to summarize the available information of Neotropical protists, focusing on metabarcoding studies, to explore what these data evidence on their ecology and biogeography. For this, we reviewed the findings from all articles that focused on or included the terrestrial protists using a metabarcoding approach and identified the gaps and future perspectives in this research field. We found that Neotropical protistan diversity patterns seem to be, at least in part, congruent with that of macro-organisms and, different than plants and bacteria, just weakly explained by environmental variables. We argue that studies with standardized protocols including different ecoregions are necessary, such as temperate forests, grasslands, and savannas from Southern of South America and Northern Atlantic Forest, to fully characterize the ecology and biogeography on Neotropical protists. Furthermore, dismembering evolutionary lineages and functional guilds of protists are important to better understand the relationship between diversity, dispersal abilities, and functionality of particular taxa of protists in their habitats.
\end{abstract}

Keywords: Environmental samples; Freshwater protists; High Throughput Sequencing; Neotropics; Microorganism; Operational taxonomic units; Soil protistan biodiversity.

\section{Ecologia e biogeografia de protistas Neotropicais usando metabarcoding: $O$ que sabemos? Para onde iremos?}

\footnotetext{
Resumo: A região Neotropical é uma das mais diversas regiões do globo em termos de espécies vegetais e animais. Em relação ao mundo microbiano, entretanto, pouco se sabe sobre a diversidade e os padrões biogeográficos dos microrganismos no Neotrópico. Nesse contexto, a biogeografia de diversos grupos taxonômicos microbianos ainda é escasso e/ou incompleto como os protistas, devido à difícil identificação taxonômica de tais microscópicos organismos. Neste contexto, o avanço dos dados moleculares de amostras ambientais (por exemplo, metabarcoding) permitiu explorar a distribuição de vários grupos de protistas. Nosso objetivo aqui foi resumir as informações disponíveis dos protistas neotropicais, com foco em metabarcoding, para explorar o que esses dados evidenciam sobre sua ecologia e biogeografia. Para isso, revisamos os resultados de todos os artigos que enfocavam ou incluíam os protistas terrestres usando uma abordagem de metabarcoding e identificamos as lacunas e as perspectivas futuras neste campo de pesquisa. Os padrões de diversidade dos protistas Neotropicais parecem ser, pelo menos em parte, congruentes com os de macroorganismos e, diferentes das plantas e bactérias, sendo pouco explicados por variáveis ambientais. Estudos com protocolos padronizados incluindo diferentes Ecorregiões são necessários, como em florestas temperadas, campos nativos e savanas no sul da América do Sul e no norte
} 
Ritter, C.D. et al.

da Mata Atlântica, para melhor caracterizar a ecologia e biogeografia de protistas Neotropicais. Além disso, é importante diferenciar linhagens evolutivas e guildas funcionais de protistas para entender melhor a relação entre diversidade, capacidade de dispersão e funcionalidade de determinados táxons de protistas em seus habitats.

Palavras-chave: Amostras ambientais; Biodiversidade do solo; Neotropicos; Sequenciamento de alto desempenho; Microrganismos; Protistas de água doce; Unidades taxonômicas operacionais.

\section{Introduction}

Despite the significant advances in our understanding of biodiversity patterns across a wide spatial scale, the question of whether the same ecological and biogeographical patterns apply to macro and microorganisms remains a discussion topic. Indeed, it was considered one of the 100 fundamental ecological questions (Sutherland et al. 2013). This knowledge gap is worrisome since microorganisms are the richest and more abundant component in any environment (Locey \& Lennon 2016, Bar-On et al. 2018), which play a pivotal role in the maintenance of ecosystems (e.g. Petersen \& Luxton 1986, Sherr \& Sherr 2002, Cuvelier et al. 2010, Steele et al. 2011). To understand the ecology and biogeography of microorganisms is, therefore, crucial to understand these patterns in general. As highlighted by O'Malley \& Dupré (2007), the excessive focus on macro-organisms patterns of diversity, ecology and distribution may have distorted several aspects of our understanding about these patterns.

Several studies have compared the diversity patterns of microorganisms with what is known for macro-organisms in a global scale (e.g. Tedersoo et al. 2014, Cameron et al. 2018, Delgado-Baquerizo et al. 2018). However, the study of several taxonomic groups is still missing and/or incomplete, such as the protists. Although some biogeographic patterns of protists in different regions are already known (Geisen et al. 2018, Singer et al. 2021), protists macroecology and biogeography is still in its infancy, and generalizations are difficult to make. It is even worse in the Neotropics, the region that comprises the area from central Mexico to Argentina, including the Caribbean (Morrone 2014). Indeed, until now just two of the articles on Neotropical protists available were used in a compilation of genomic data to test ecological patterns on global terrestrial protists (Oliverio et al. 2020). Furthermore, the hard-taxonomic identification of protists contributes to the lack of sampling in some regions, reflecting the uncertainties on ecological and biogeographic patterns. Advanced molecular techniques such as environmental DNA sampling known as metabarcoding brings promising prospects for protists (Santoferrara et al. 2020). Our goal here was to summarize the findings concerning protistan distribution through metabarcoding data from continental environmental samples in Neotropics to understand the ecological processes underlying the biogeography of the protists in this region. We also identified the main gaps in the Neotropical protists ecology and biogeography and to shed light on the already described patterns and potential prospects in this so promising study group. First, let us introduce this group here, who they are, what is known about their ecology, and then, how molecular techniques such as metabarcoding can bring new advances to the knowledge of this amazing group.

\section{The protists}

\subsection{Who are they? Where do they live? How do they survive?}

The protists are a paraphyletic group comprising most lineages in the eukaryotic tree of life (Keeling et al. 2005, Burki 2014). Several groups are closer related with macro-organisms, such the phyla Opisthosporidia,
Nucleariida and Fonticula that are inside of the Holozoa, group that comprise Fungi and Metazoa (Burki 2014, Adl et al. 2019). Protists are the non-fungi single cell eukaryotes that are over spread in the tree of life and have the potential to shed light on eukaryotic evolution (Adl et al. 2019). Future perspectives include the deep phylogeny of protists and better characterization of phylogenetic and functional diversity for advance knowledge of this amazing group(s).

Protists inhabit all habitats, from soils, lakes, sea, and the bodies of other organisms (Figure 1). They are mostly known to be vector of diseases such as Malaria (caused by Plasmodium sp.), Chagas (caused by Trypanossoma cruzi), Giardisis (caused by Giardia sp.) and Toxoplasmosis (caused by Toxoplasma gondii). However, the protists have a diverse lifestyle from free-living forms to parasites of other animals, plants and even other protists (Adl et al. 2019). Furthermore, they are highly abundant organisms in any given location. For instance, current estimates suggested between 50,000 to 100,000 protist species in the sunlit surface layer of the global ocean, five to ten times more than bacteria and archaea combined (De Vargas et al. 2015). In terrestrial environments, the protists species number is more controversial, with no clear approximation of species number but an estimation of tens of thousands of individuals per gram of bulk soil (Finlay 2002, Stefan et al. 2014). In addition, protists play a key role in the ecosystems, such as the primary production carried out by photosynthetic protists, which is the base of food chains in freshwater and marine environments (Worden et al. 2015), while the heterotrophic protists are crucial in the nutrient recycling through decomposition in water, sediments, and soils (de Araujo et al. 2018). The advance in our knowledge of protistan diversity and distributions in nature is mainly due to the use of molecular approaches that allow sampling of thousands of protists at once.

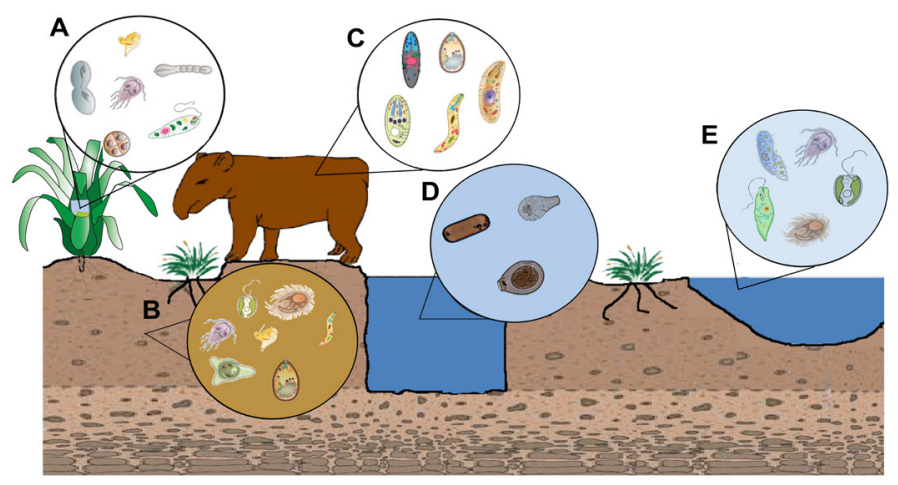

Figure 1. Schematic design of the main groups of protists found in the different environments in Neotropics. The circles represent the zoom showing the most common protists in each environment. A) the phytotelmata of bromeliads plants where was found several Ciliophora and Flagellates; B) soil protists that are mostly represented by Alveolata (mostly Apicomplexa), Dinophycea, Cercozoa and Ciliophora; C) the animal bodies that are occupied by parasitic protists such Apicomplexa; D) river environments that presents several species of Testade Amoebae; and E) lakes with the dominance of Discoba (mainly Euglenidaes), Ciliophora and Ochrophyta. 


\section{Molecular approaches to assess protists diversity}

The difficulty to sample, identify and test ecological and biogeographical questions in protists (and micro-organisms in general) are mainly due to the hard-taxonomic and time-consuming identification. The taxonomic classification based on morphological characters of almost "invisible" organisms is extremely limited and needs very experienced taxonomists. Several studies on protists using microscopy, incubation and biochemistry-based methods for morphological or functional identification have been done (e.g. Adl \& Gupta 2006). However, due to the difficulty of identification, these studies are focused in a limited group such as testate amoebae (e.g. Lansac-Tôha et al. 2014) or planktonic ciliates (e.g. Negreiros et al. 2017).

In this context, high-throughput sequencing (HTS) of environmental DNA have revolutionized the taxonomic identification of microbes in above- and below-ground communities (Bik et al. 2012, Deiner et al. 2017), including protists (Santoferrara et al. 2020). One powerful method for diversity assessment in a given locality is metabarcoding. This technique improves the biodiversity assessment from microbes to mammals and, with that, promises innumerable advances in several fields, including ecology, biogeography and evolution (Compson et al. 2020). These advances follow developments in the identification of barcoding sequences of species and the existence of public and relatively highly populated reference sequence databases.

The idea of DNA barcode is based on that some DNA regions are conserved enough to have little intraspecific variation but variable enough to distinguish species, so the use of a specified DNA sequence provides taxonomic identification for a specimen (Blaxter 2004). The metabarcoding idea is similar, but instead of sequencing the DNA from one specimen, we can use environmental samples, such as soil, water and air to extract all DNA present in these samples to amplify by Polymerase Chain Reaction (PCR). After amplification, we sequencing a specific DNA region, that can be analyzed for all genetic variation with amplicon sequence variants (ASV; Callahan et al. 2017) or can be grouped by a threshold of similarity (usually $97 \%$ ) in operational taxonomic units (OTUs; Blaxter et al. 2005), to identify a phylogenetic range of organisms from a set of specimens or even entire communities (Taberlet et al. 2018). From these molecular data it is possible to fill gaps about the knowledge of microorganisms in regions with sample deficits, such as the Neotropics, more efficiently, and consequently to better describe the patterns of diversity and distributions of microorganisms on a massive scale.

\section{Material and Methods}

We performed the literature review on the bibliographic databases from Web of Science and Google Scholar on April 9, 2019 and updating on August 28, 2020 using the keywords "Eukaryotes" OR "Protists" OR "Protista" AND "metabarcoding" OR "Environmental DNA" AND "Neotropics" OR "Neotropical". Subsequently, the literature was filtered, selecting only metabarcoding studies with continental protists from the Neotropics. We read all the articles resulting from this filtering and selected the important information, chronologically, for new advances in biogeography and ecology of Neotropical protists. In addition, we compiled information about which groups were identified and the locations of the collections, extracting the geographic coordinates of those locations when available.

\section{Results}

\section{Biogeography of Neotropical Protists: What we know.}

In the 90's the idea of microbial biogeography was guided for the famous sentence "everything is everywhere - but the environment selects" (Becking 1934, De Wit \& Bouvier 2006). While the first proposition implies that microorganisms have dispersal abilities so high that the effects of past processes are suppressed, the second assumes that current environmental characteristics select different microbial taxa according to their habitat preferences (De Wit \& Bouvier 2006). However, the recent advance of genetics allowed a deep sampling of microorganisms and this sentence started to be refuted throughout the world (Finlay \& Fenchel 2005, Foissner 2006, Bass et al. 2007, Bates et al. 2013), including some Neotropical representability of samples (Bates et al. 2013, Lentendu, Buosi, et al. 2018). Although both cosmopolitan species were registered (de Vargas et al. 2015) and spatial patterns linked to environmental heterogeneity (Logares et al. 2018) were observed, biogeographical patterns related with long-term climatic and geological processes had already been identified (e.g. Singer et al. 2019). Most of the idea of over-dispersal and cosmopolite occurrence of microorganisms was due to the morphology-based classification that groups several species into a "morphospecies", misidentifying and not identifying some many other species. For instance, using metabarcoding analysis the dispersal limitation was identified in both terrestrial (Singer et al. 2019) and marine environments as the main factor structuring micro-eukaryotes communities (Logares et al. 2020).

The Neotropics presents strong biogeography patterns already recognized for vertebrates and plants (e.g. Alfaro et al. 2015, EsquivelMuelbert et al. 2017, Carneiro et al. 2018). These biogeographical patterns are related with the highly diverse in both Neotropical biomes and habitats, such as the Andes mountains, tropical rainforests, seasonally flooded areas, savannas, and large dry areas (Hughes et al. 2012, Fig. 2; Olson et al. 2001). Among some of the known biogeographical patterns there are the west-to-east diversity gradient in Amazonia which was suggested been explained by marine incursions (Bates 2001, Lovejoy et al. 2006), bedrock geology (Tuomisto et al. 2017), mountain base formation (Hoorn et al. 2010), soil fertility (ter Steege et al. 2006, Hoorn et al. 2010) and diversification process driven by moisture (Silva et al. 2019). Another pattern is the endemism present in areas of Amazonia (Cracraft 1985, Ribas et al. 2012), Atlantic Forest (Costa et al. 2000, Silva \& Vaz-de-Mello 2020) and Cerrado savanna (Azevedo et al. 2016). Other patterns include the high species turnover, the increase of community dissimilarity with geographical distance, also known as the distance-decay relation in the Neotropical forests (Bohlman et al. 2008), body-size habitat specialization (e.g. Hillebrand \& Azovsky 2001, Lafferty \& Kuris 2002, Woodward et al. 2005, Abades et al. 2010) and tree species density-dependent host-specific predation and parasitism (Janzen 1970, Connell 1971). Although in a limited number, some studies investigate such patterns for Neotropical protists using the metabarcoding approach (Table 1). Below we discuss each study and its advances individually.

Creer et al. (2010) were the first to sample Neotropical soil protists in one of the first environmental metabarcoding studies that evaluated the effectiveness of using Roche/454 sequencing technology to uncover the meiofauna in specific and complex eukaryotic communities in general. They sampled four sites in a secondary plot at La Selva Biological 
Station in Costa Rica (Figure 2), as well as marine littoral benthic off the south coast of England. The 18S-rRNA primers that were used were designed to primarily amplify the Nematoda (Porazinska et al. 2009), which was the targeted meiofaunal taxon in this study. Although not designed to amplify all eukaryotes broadly, the primers also amplified numerous protist taxa. In their taxonomic assignment of the OTUs, they lumped all of the OTUs assigned to the protists as "protozoa" but did not break that group down into smaller taxa.

Later, Bates et al. (2013) published the first study targeting protists communities using a metabarcoding approach including the Neotropics being the first with the goal to investigate the diversity and biogeographic patterns of Neotropical soil protists. They sampled several regions in the Americas, including the Neotropics regions of the Caribbean, the Southwest Amazonia in Peru and the Northeast of Argentina (Figure 2). They found a biogeographical pattern for soil protists with just one of the 1,014 OTUs found having a cosmopolitan distribution. Furthermore, they found that the environmental factors, such as edaphic (e.g. pH) and climatic (e.g. temperature) variables, knowing to strongly affect the diversity of plants, animals and soil bacteria had just a moderate effect on soil protistan diversity, while soil moisture was the most important, yet moderate, edaphic variable to explain protistan diversity.
Even with Bates et al. (2013) showing the potential of molecular studies revealing the ecological and biogeographical patterns of protists in Neotropics, the next studies targeting protists were published four years later (Simão et al. 2017, Mahé et al. 2017). Simão et al. (2017) sampled four bromeliads phytotelmata (plant-container habitats) in the Atlantic Forest of Southern Brazil (Figure 2). They used primers to amplify the V9 region of the 18S-rRNA locus (Nolte et al. 2010) in the Illumina DNA sequencing platform to survey the eukaryotic communities, especially ciliates, inhabiting these bromeliads phytotelmata. They found remarkably diverse eukaryotic communities, with Arthropoda and Ciliophora showing the highest abundance. Moreover, a high abundance of both free-living protists (ciliate genera Tetrahymena and Glaucoma) and animal parasites (the apicomplexan gregarines and the genus Trypanosoma) was found. They argue that the high abundance of animal parasitic protists in bromeliad tanks indicates that these organisms and their vectors use phytotelmata as a common habitat. Their results showed a hidden diversity of eukaryotes in bromeliad phytotelmata, even with limited sampling (just four phytotelmatas), shedding light on the studies of plant-protist-animal interactions.

Mahé et al. (2017) sampled multiple lowland tropical rainforests with the aim of uncovering protistan diversity in Neotropical soils. They

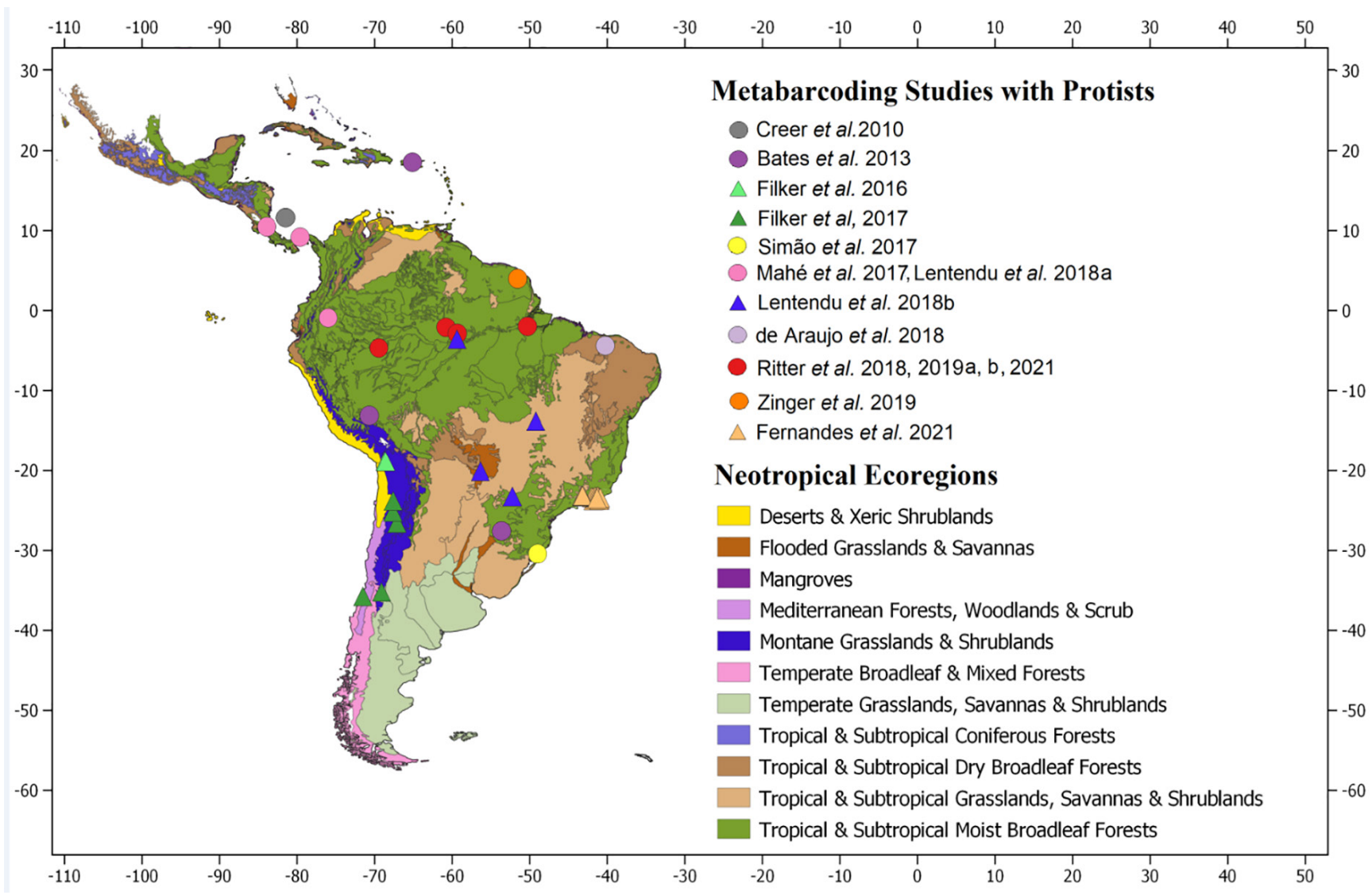

Figure 2. Neotropical Ecoregions with the areas that samples protists. The circles represent the studies location. Studies that used the same data are cited a by

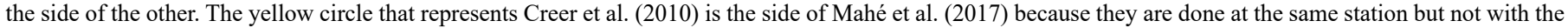
same methodology and the exact same locations. Squares represent terrestrial and triangles the aquatic studies. It is possible to observe the little number of studies on Neotropics with a concentration on forests. A big gap on sampling of other ecoregions such as Andes, dry areas, tempered Neotropical regions, deserts and xeric vegetation is notable. Ecoregions shape file from Dinerstein et al. (2017) licensed under CC-BY 4.0 (https://creativecommons.org/licenses/by/4.0/). Map was created with QGis v.3.6.2 (https://www.qgis.org/) licensed under CC-BY-SA 3.0 (https://creativecommons.org/licenses/by-sa/3.0/). 
Table 1. Studies using metabarcoding approach that includes Neotropical protists. All studies amplified the nuclear ribosomal 18S rRNA small subunit (18S) gene, but different regions of this gene. The protistan taxa sampled are variable, and with the limited number of studies, type of sample and DNA region, generalization are hard.

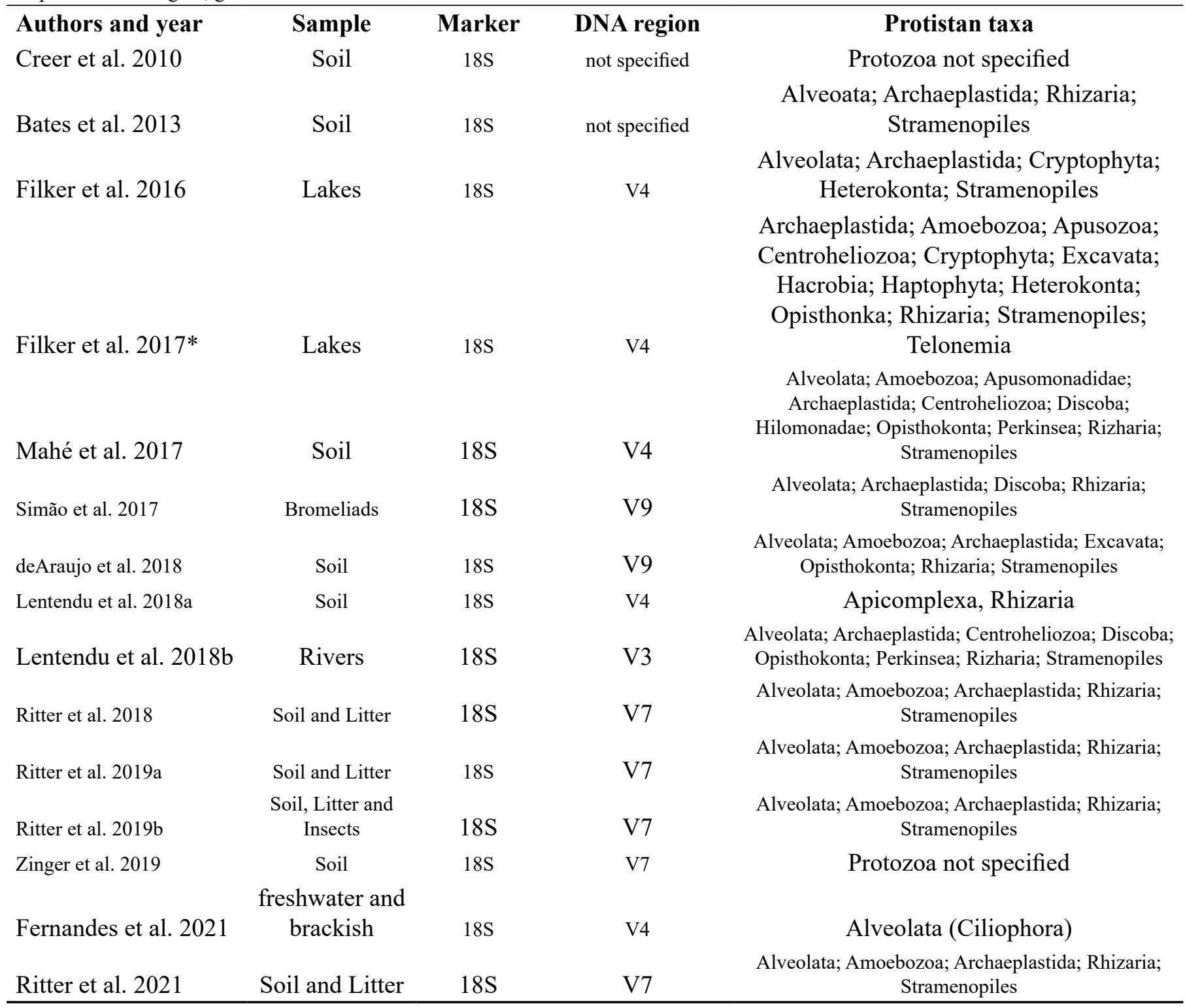

*Filker et al. 2017 did not split protistan sampled in Neotropical lake from African and European Lakes.

sampled over two years in older growth plots in La Selva Biological Station, Barro Colorado Island in Panama, and Tiputini Biodiversity Station in Ecuador (Figure 2). The primers that were used were designed to amplify the hypervariable V4 region of the 18S-rRNA locus in all eukaryotes. The protistan soil communities in all three countries were found to be dominated by OTUs taxonomically assigned to the parasitic Apicomplexa, which are all parasites of animals (Rueckert et al. 2019). Although some of these apicomplexans are from the Haemospororida, which includes Plasmodium and close relatives that infect arthropods and vertebrates, most of the apicomplexans are from the Gregarinasina the predominantly infect arthropods and other invertebrates (Adl et al. 2019).

Mahé et al. (2017) suggested that this massive diversity of apicomplexans could potentially contribute to more animal species coexisting together in the tropical forests because of density-dependent parasitism. This "Mahé-Dunthorn" hypothesis for animals mirrors the Janzen-Connell hypothesis (Janzen 1970, Connell 1971) for densitydependent in host-specific predation and parasitism contributing to more tropical tree species being able to coexist. It should be noted that there are other hypotheses for high animal species coexistence in tropical forests, but these have focused on how the increased number of plant species affects herbivorous insects, and to a lesser extent other arthropods (Novotny et al. 2006, Basset et al. 2012, Becerra 2015). However, not all of the high animal diversity in tropical forests can be explained or predicted by plants alone. In contrast to the apicomplexans, there were few parasitic oomycetes OTUs in the protists soil communities in three countries. Mahé et al. (2017) argued that there were too few oomycetes to be an important group for the density-dependent host-specific parasitism under the Janzen-Connell hypothesis. Although oomycetes were long thought to be major host- 
specific parasites (Freckleton \& Lewis 2006), they were also not found to have an effect on plant communities in a fungicide- and insecticidestudy in Belize (Bagchi et al. 2014).

Using the same data as Mahé et al. (2017), Lentendu et al. (2018) evaluated the taxa-area relationships and the distance-decay relationships on soil Neotropical protists (Figure 2). While taxa-area relationships measure the increasing number of species or richness with the increase of sampled area (Arrhenius 1921, Drakare et al. 2006), distance-decay relationships focus on community composition and measures the increase of communities' dissimilarity with the increase of distance (Soininen et al. 2007, Morlon et al. 2008). These patterns were tested in macro-organisms in tropical forests showing a high alpha (local - Condit et al. 1996, Basset et al. 2012) and low beta (regional Plotkin et al. 2000, Condit et al. 2002) diversity. For the parasitic and free-living protists, a similar high alpha and low beta diversity pattern was found among Neotropical forests (Lentendu, Mahé, et al. 2018). These results showed the congruence with Neotropical biogeographic patterns between macro and microorganisms and indicate that these organisms are spatially structured, at least in part, for the same general process. Yet, which process molds this Neotropical diversity patterns should be further investigated.

de Araújo et al. (2018) sampled Neotropical soils protists from transitions zones between the Tropical Dry Forests and the Brazilian Cerrado (Figure 2), the most diverse savanna in the world in terms of animals and plants (Furley 1999, Myers et al. 2000). They sampled four vegetation zones in the Sete Cidades National Park, Brazil. They also used Illumina sequencing technology with the aim of uncovering protistan diversity and co-occurrence in Neotropical savanna. The primers used were designed to amplify the hypervariable V9 region of the 18S-rRNA locus in all eukaryotes. Considering the vegetation coverage, the Brazilian Cerrado can be classified in four vegetation succession zones: from grass, grass and shrub, shrub and tree, and tree-dominated climax vegetation zone (Coutinho 1978, Furley 1999). These zones show a plant diversity gradient (de Araujo et al. 2018) and are also related with animal diversity (da Silva \& Bates 2002, Mares \& Ernest 2019) but see Nogueira et al. (2009) that shows a mismatch between vegetation and animal diversity in the Cerrado. Using this vegetation zone classification, de Araujo et al. (2018) compared soil protists richness and microbiome complexity, combining protists with prokaryotic and fungal sequences, through co-occurrence network analysis. Both protistan richness and microbial complexity were higher in tree-dominated zones (de Araujo et al. 2018). Also, the soil protists composition was different between zones with the plant-parasites and omnivores being more abundant in grass zones and animal parasites in grass-shrub zones (de Araujo et al. 2018). They suggested that protists are key soil microbial components and that vegetation succession towards climax vegetation, and consequently higher animal and plant diversity, is stimulated by higher loads of animal and plant pathogens. Furthermore, the authors suggested higher system stability with an increase in microbial complexity.

Ritter et al. (2019) also compared patterns between animals and plants with soil Neotropical microorganisms. They sampled litter and soils in 39 plots at four localities across a large longitudinal range in Brazilian Amazonia (Figure 2). Localities were selected to maximize west-to-east diversity gradient in Amazonia (ter Steege et al. 2003, Bass et al. 2010, Hoorn et al. 2010, Zizka et al. 2018) and the number of vegetation (habitat) types with characteristic biota and environmental conditions (ter Steege \& Hammond 2001, Haugaasen \& Peres 2006, Assis et al. 2015, Adeney et al. 2016, Myster 2016). These habitats include, in a decreasing macro-organisms' diversity gradient: nonflooded rainforests (terra-firme), forests seasonally flooded by fertile white waters (várzeas) or by unfertile black waters (igapós), and naturally open areas associated with white sand soils (campinas). They found that microorganisms' richness (including protists) and community composition differ significantly among localities and habitats, and that habitat type strongly structured microbial composition than locality. Ritter et al. (2019) detected a different habitat gradient from the expected, but as expected they found a west-to-east longitudinal gradient for microbial richness and community composition. The authors, in another study, explicitly tested the birds and tree diversity against protists (and other microorganisms) diversity (Ritter, Faurby, et al. 2019) showing that the currently accepted diversity patterns in Amazonia just partially match for macro and microorganisms.

Furthermore, these data were used to test soil chemical-physical variables to explain the richness and diversity of Amazonian microorganisms (Ritter et al. 2018). They found a positive correlation for $\mathrm{pH}$ and a negative correlation for soil organic carbon content with respect to microbial diversity, suggesting that physicochemical soil properties can predict, to some extent, microbial soil, and litter diversity in Amazonia. However, the author did not test physicochemical soil properties directly with just protistan diversity. In another study, the authors explored the ecological network of these soil and litter organisms and the importance of soil properties in the co-occurrence and co-exclusion patterns (Ritter et al. 2021). They found that mostly protists were specialists (occurring in just one habitat type), yet they were registered in the co-occurrence networks. Most protists recovered in the networks belong to the supergroup SAR (mostly Rhizaria, followed by Alveolata, and Stramenopiles) followed by Amebozoa (Ritter et al. 2021). The networks were dominated by bacteria, what can explain the highest predominance of protists that feed on bacteria and some on fungi (or both), with few eukaryotic parasites (Ritter et al. 2021). The soil properties do not explain protists co-occurrence neither their co-exclusion, although several soil properties are important factor in the co-exclusion networks considering all soil organism (bacteria, chloroplastida, fungi, metazio, and protists; Ritter et al. 2021).

Zinger et al. (2019) explored the role of environmental selection (i.e., soil properties, biotic interactions) and stochastic distancedependent neutral processes (i.e., demography, dispersal) in shaping soil communities, including protists (Table 1), considering the effect of body sizes. Body size is known to be important to determine ecological and biogeographical patterns in the organisms (e.g. Hillebrand \& Azovsky 2001, Lafferty \& Kuris 2002, Woodward et al. 2005, Abades et al. 2010). In this study, they sampled 1,132 soils from a 12 ha Neotropical forest plot in Nouragues Ecological Research Station, French Guiana (Figure 2). They found that the distribution of protists is primarily stochastic, suggesting that, at least on a regional scale (12 ha), neutral processes are important factors to shape the protistan soil community. Other weak but significant drivers of the soil protistan richness and composition include aluminum, topography, and plant species. Together, these studies showed a mix of deterministic and stochastic factors shaping Neotropical protistan biogeography and ecology. However, such scale does not include historical factors and some biotic variation as 
temperature and precipitation. It highlights the need of more extensive studies to understand the patterns and drivers of the distribution of Neotropical protists.

It is also worth mentioning that even more scarce is the knowledge about the biogeography of aquatic protists in the Neotropics. As far as we know, only four articles published so far have explored distribution patterns of Neotropical protists in continental waters through metabarcoding (Filker et al. 2016, 2017, Lentendu, Buosi, et al. 2018, Fernandes et al. 2021). Filker et al. (2016) studied planktonic protists of high-mountain lakes in the Chilean Altiplano using the V4 region of the 18S-rRNA locus, and Lentendu et al. (2018a) studied planktonic protists in Brazilian lakes using the $\mathrm{V} 3$ region of the 18S-rRNA locus. In these two articles, the authors have found that the freshwater protists were not globally distributed, but that different communities exhibited particular taxonomic compositions both within the Neotropical (Lentendu, Buosi, et al. 2018) and when compared with other regions of the globe (Filker et al. 2016). The third article explored the distribution of halophilic aquatic protists, using the V4 region of the SSU rDNA locus, in shallow salt ponds with different degrees of salinity from South America and Europe (Filker et al. 2017). In this study, differently from Eastern Antarctica (Logares et al. 2018), salinity was more important than geography in structuring protistan communities. Moreover, a high rate of endemism was observed. Recently, Fernandes et al. (2021) investigated the diversity of ciliates in freshwater and brackish environments along the Atlantic Forest using the hypervariable V4 region of the 18S-rRNA. They found that ciliate communities are more diverse in freshwater than in brackish environments, in agreement with Filker (2017). Interestingly, they also showed that a considerable fraction of the diversity of Atlantic Forest ciliate species detected by HTS is not represented in the molecular databases currently available, since they recorded 409 taxonomic units of ciliate at a $97 \%$ similarity level, but could attributed in only 144 species (Fernandes et al. 2021).

\section{Discussion}

\section{Gaps and prospects: where do we go?}

Although more than 350 articles using metabarcoding approaches that include protists are published until now (Santoferrara et al. 2020), for our knowledge, there are just 11 articles including terrestrial protists in the Neotropics (Figure 2). Among them, we have several sampling designs, different primers set and sequencing methods that make comparisons impossible (Table 1). To grasp the protistan biogeographic and ecological patterns, studies with standardized methods across the different ecoregions comparing the geographical and environmental distance are essential (Martiny et al. 2006).

Several factors are important to consider when using molecular tools in biodiversity assessments, including sampling design, DNA extraction protocols, choice of genetic marker, sequencing method, and data analysis procedures (Ritter, Häggqvist, et al. 2019, Zinger, Bonin, et al. 2019, Compson et al. 2020). For instance, a serious caveat for using a metabarcoding approach for protists biodiversity assessments is the primer choice that oversample some groups and under-sample others. Indeed, although the most used marker to sample protists with metabarcoding is the nuclear ribosomal $18 \mathrm{~S}$ rRNA small subunit (18S) gene, many different primers in various combinations, targeting different
18S gene regions were used (Geisen et al. 2019, Santoferrara et al. 2020). Although just 11 studies are made for Neotropical protists, at least three regions of $18 \mathrm{~S}$ gene were used. It is important to standardize the gene region and primers used to allow a more truthful comparison between studies.

Beyond standardizing primer to study in a broader scale Neotropical protists, new techniques, yet underexplored in the Neotropics, can help to unveil protistan biogeography and ecology and may overcome some biases of PCR. For instance, metatranscriptomics, the RNA sequencing of environmental samples, uses a primer-free approach that can pick up different parts of the same gene and uncover taxa not amplified by common amplicons (Geisen et al. 2015, Cristescu 2019). Other techniques include PCR-free DNA targeted-sequencing (Shokralla et al. 2016, Giebner et al. 2020), non-targeted, reduced-representation of whole genome (Hand et al. 2015), and whole-genome skimming (Coissac et al. 2016). In addition, single-molecule DNA sequencing technologies such as Oxford Nanopore and Pacific Biosciences (PacBio) can sequence bigger fragments allowing a better taxonomic resolution (Thompson \& Milos 2011, Jamy et al. 2020, Ritter et al. 2020). The advances in molecular based studies have the potential to allow further investigation of the distribution of Neotropical protists and their drivers.

Another problem is the lack of sequence reference databases for several taxonomic groups, especially for the tropical regions (Zinger et al. 2020). Without such reference databases, the recovered sequences cannot be matched to resolved taxonomic levels (Fernandes et al. 2021). However, phylogenetic placement of lineages without sequence reference can uncover this caveat. For instance, lineages of shortbranch Microsporidia were recently uncovered in a re-analysis of a metabarcoding study of Neotropical rainforest soils (Bass et al. 2018). Short-branch Microsporidia are a parasitic group, and it is expected that these environmental lineages are also parasitic, but no information about their ecology are available. Even so, using co-occurrence network analysis Doliwa et al. (2020) identified potential hosts of these lineages, showing that high-throughput DNA sequencing studies of biodiversity assessment form a powerful tool to explore entire communities and to understand their biotic/abiotic interactions.

Although it is hard to differentiate environmental filters from species interaction using co-occurrence network analysis (Blanchet et al. 2020), it could help to unravel the patterns and drivers of Neotropical protists diversity and distributions (Mikhailov et al. 2019). For instance, de Araujo et al. (2018) showed the relationship between plants and protists, adding the influence of different environmental zones and the co-occurrence patterns between microorganisms. Also, Ritter et al. (2021) showed a high co-occurrence of protists bacterivorous with bacteria in Amazonian soils. The study by Simão et al. (2017) reveals an important point for advances in studies of Neotropical protists, showing a hidden diversity of eukaryotes in phytotelmata of bromeliads, which can be explored in future studies covering other biotic interactions as well as comparing differences on environmental factors that affect these interactions along Neotropical ecoregions. These studies reveal the importance of studies embracing different interactions between protists and other organisms, as well as between environments as key components of the ecosystem. Therefore, there is still a gap to be filled in relation to these issues, representing good perspectives for future studies.

The Neotropical biogeographic patterns in protists seem to be, at least in part, congruent with that of macro-organisms (Lentendu, Mahé, 
et al. 2018) despite the enormous difference between these groups. These similarities can be explained by similar filters or by biotic interactions, for instance, parasitic protists must have similar distribution of their hosts. These findings are extremely important and should be further investigated to understand whether they represent the same processes at work or if different processes lead to the same patterns between these groups. Common themes in Neotropical biogeography of macro-organisms, such as the impact of uplifting the Andes on the distribution and evolution of biotas (Hoorn et al. 2010) and the Great American Biotic Interchange (Stehli \& Webb 2013, Antonelli et al. 2018) remain unexplored for Neotropical protists. In addition, there is a huge difference within the group itself, which deserves to be better explored.

Protists are a highly diverse group not just in terms of the number of species but also in terms of functional ecology that may affect their distribution (e.g. Weisse 2017, Adl et al. 2019). Then, which differences can we expect in the ecological and biogeographical patterns between different groups of protists? This type of approach would be remarkably interesting for the field. It is possible to explore the differences between biogeographic patterns in protists with different types of mobility (e.g. ciliate versus flagellate), reproduction (several types of asexual and sexual reproduction cycles), cell shape (several types of cell wall/theca), cell organization (unicellular, filamentous, and colonial) metabolism (heterotrophic, autotrophic and mixotrophic) and preferences habitat (wetlands, aquatic, terrestrial, and in association with other organisms).

In addition, phototrophs protists dominated freshwater systems while consumers dominated soil ecosystems (Logares et al. 2018, 2020). Yet, the extent importance of historical, geographical, and ecological factors to determine both aquatic and terrestrial protists is an important issue to be investigated to understand patterns and drivers of protists distribution. Considering the several types of continental aquatic ecosystems (freshwater and salt reservoirs, ponds, lakes, and rivers), it is important to compare the protistan diversity and composition in these environments in order to fully characterize this group in the Neotropics. Furthermore, protists are great models to generate new insights of Neotropical ecology and biogeography due to some species having high dispersal rates (Geisen et al. 2014) that allow quantifying the relative importance of niche and stochastic in structuring biological communities. On the other hand, endemic protists (Ryšánek et al. 2015) can be great models for testing the role of speciation, local adaptation and dispersal limitation (Singer et al. 2019, Logares et al. 2020). Also, due to their short generation time and consequently high speciation rates, they can potentially lead to the convergence of ecological and evolutionary time scales.

Another important gap to be filled in biogeographic studies of Neotropical protists is the sample coverage throughout this widely diverse region. Much of the tropical rainforest region of eastern South America (covering the North of the Atlantic Forest) still needs to be sampled and studied, in terms of metabarcoding (Figure 2). In addition, the temperate regions of the Neotropics also lack biogeographic studies using molecular protist approaches (Figure 2). It will also be important to fill the study gaps in Neotropical savannas, which have their only sampling in the Cerrado savannas as well as the Dry Forests. The altitude gradient, that strongly structure macro-organisms (Mateo et al. 2012, Li et al. 2019, Veintimilla et al. 2019, Villamarín et al. 2020) and some micro-organisms (Meng et al. 2013, Siles \& Margesin 2016, Peay et al.
2017, Shen et al. 2020) may be widely tested for protists in Neotropical regions as these sample gaps are filled with metabarcoding studies.

Beyond the improvement in taxonomic and spatial coverage, it is also important to include abundance metrics since density-dependent factors are crucial to understand the biogeographic and ecological patterns (Martiny et al. 2006). Density-dependent factors include competition, predation and parasitism (Ricklefs 2008). Even so, most evidence for density dependence diversity control is plant-based (e.g. Hector et al. 1999, Hooper et al. 2005). However, a study showed that while niche complementarity and density-dependent effects can produce a diversityproductivity saturation curve in plants, soil-transmitted microorganisms were the major determinants of the relationship (Schnitzer et al. 2011). On the other hand, diversity in biological communities is also a historical product of immigration, diversification and extinction (Fukami \& Morin 2003, Fukami et al. 2007). However, these processes are still poorly studied in protists, even less so in the Neotropical region. Therefore, we highlight the need for more extensive studies to understand the patterns and drivers of the distribution of Neotropical protists, covering these regions with gaps, as well as the points highlighted above.

\section{Conclusions}

Here we review the available information of metabarcoding for Neotropical protists and put it together to better understand their ecological and biogeographical patterns. Together our review shows that: 1) much more information is needed to explore the Neotropical protists diversity, ecology and biogeography; 2) Neotropical protists diversity patterns seem to be, at least in part, congruent with that of macro-organisms; 3) studies with focus on protist that split at least the main groups that could identify lineages and guilds are important to better understanding the ecosystem function of each group in their habitats; and 4) environmental variables weakly explain protists distribution in both regional to more broad scale, however, standardized studies including different biomes are necessary to better address these patterns.

\section{Acknowledgments}

Funding came from the Alexander von Humboldt Foundation's Fellowship for Postdoctoral Researchers to CDR, and the Deutsche Forschungsgemeinschaft (grant DU1319/5-1) to MD.

\section{Author Contributions}

Camila Duarte Ritter: Responsible for the concept and design of the study; collected, analyzed, and interpreted the data; write and reviewed the manuscript contributing to critical review, adding intellectual content

Arielli Fabrício Machado: Collected, analyzed, and interpreted the data; write and reviewed the manuscript contributing to critical review, adding intellectual content

Karine Felix Ribeiro: Collected, analyzed, and interpreted the data; write and reviewed the manuscript contributing to critical review, adding intellectual content

Micah Dunthorn: Responsible for the concept and design of the study; write and reviewed the manuscript contributing to critical review, adding intellectual content. 


\section{Conflicts of Interest}

The authors declare no conflict of interest.

\section{References}

ABADES, R., LAUFER, G., LOUREIRO, M. \& MARQUET, P.A. 2010. Food web structure and body size : trophic position and resource acquisition. (June 2009):147-153.

ADENEY, J.M., CHRISTENSEN, N.L., VICENTINI, A. \& COHN-HAFT, M. 2016. White-sand ecosystems in Amazonia. Biotropica 48(1):7-23.

ADL, M.S. \& GUPTA, V.S. 2006. Protists in soil ecology and forest nutrient cycling. Can. J. For. Res. 36(7):1805-1817.

ADL, S.M. et al. 2019. Revisions to the Classification, Nomenclature, and Diversity of Eukaryotes. J. Eukaryot. Microbiol. 66(1):4-119.

ALFARO, J.W.L., CORTÉS-ORTIZ, L., DI FIORE, A. \& BOUBLI, J.P. 2015. Special issue: Comparative biogeography of Neotropical primates. Mol. Phylogenet. Evol. 82(PB):518-529.

ANTONELLI, A. et al. 2018. Conceptual and empirical advances in Neotropical biodiversity research. PeerJ 2018(10):

DE ARAUJO, A.S.F., MENDES, L.W., LEMOS, L.N., ANTUNES, J.E.L., BESERRA, J.E.A., DE LYRA, M. do C.C.P., FIGUEIREDO, M. do V.B., LOPES, Â.C. de A., GOMES, R.L.F., BEZERRA, W.M., MELO, V.M.M., DE ARAUJO, F.F. \& GEISEN, S. 2018. Protist species richness and soil microbiome complexity increase towards climax vegetation in the Brazilian Cerrado. Commun. Biol. 1(1):135

ARRHENIUS, O. 1921. Species and area. J. Ecol. 9(1):95-99.

ASSIS, R.L., HAUGAASEN, T., SCHÖNGART, J., MONTERO, J.C., PIEDADE, M.T.F. \& WITTMANN, F. 2015. Patterns of tree diversity and composition in Amazonian floodplain paleo-várzea forest. J. Veg. Sci. 26(2):312-322.

AZEVEDO, J.A.R., VALDUJO, P.H. \& DE C. NOGUEIRA, C. 2016. Biogeography of anurans and squamates in the Cerrado hotspot: coincident endemism patterns in the richest and most impacted savanna on the globe. J. Biogeogr. 43(12):2454-2464.

BAGCHI, R., GALLERY, R.E., GRIPENBERG, S., GURR, S.J., NARAYAN, L., ADDIS, C.E., FRECKLETON, R.P. \& LEWIS, O.T. 2014. Pathogens and insect herbivores drive rainforest plant diversity and composition. Nature 506(7486):85-88.

BAR-ON, Y.M., PHILLIPS, R. \& MILO, R. 2018. The biomass distribution on Earth. Proc. Natl. Acad. Sci. 115(25):6506-6511.

BASS, D., CZECH, L., WILLIAMS, B.A.P., BERNEY, C., DUNTHORN, M., MAHÉ, F., TORRUELLA, G., STENTIFORD, G.D. \& WILLIAMS, T.A. 2018. Clarifying the relationships between microsporidia and cryptomycota. J. Eukaryot. Microbiol. 65(6):773-782.

BASS, D., RICHARDS, T.A., MATTHAI, L., MARSH, V. \& CAVALIERSMITH, T. 2007. DNA evidence for global dispersal and probable endemicity of protozoa. BMC Evol. Biol. 71-13.

BASS, M.S., FINER, M., JENKINS, C.N., KREFT, H., CISNEROS-HEREDIA, D.F., SHAWN, F., PITMAN, N.C.A., ENGLISH, P.H., SWING, K., VILLA, G., FIORE, A. Di, VOIGT, C.C. \& KUNZ, T.H. 2010. Global Conservation Significance of Ecuador' s Yasunı National Park. 5(1):

BASSET, Y., CIZEK, L., CUÉNOUD, P., DIDHAM, R.K., GUILHAUMON, F., MISSA, O., NOVOTNY, V., ØDEGAARD, F., ROSLIN, T. \& SCHMIDL, J. 2012. Arthropod diversity in a tropical forest. Science (80). 338(6113):1481-1484.

BATES, J.M. 2001. Avian diversification in Amazonia: evidence for historical complexity and a vicariance model for a basic diversification pattern. Divers. biológica e Cult. da Amaz. 119-137.

BATES, S.T., CLEMENTE, J.C., FLORES, G.E., WALTERS, W.A., PARFREY, L.W., KNIGHT, R. \& FIERER, N. 2013. Global biogeography of highly diverse protistan communities in soil. ISME J. 7(3):652-659.

BECERRA, J.X. 2015. On the factors that promote the diversity of herbivorous insects and plants in tropical forests. Proc. Natl. Acad. Sci. 112(19):6098-6103.

BECKING, L.G.M.B. 1934. Geobiologie of inleiding tot de milieukunde. WP Van Stockum \& Zoon.
BIK, H.M., PORAZINSKA, D.L., CREER, S., CAPORASO, J.G., KNIGHT, R. \& THOMAS, W.K. 2012. Sequencing our way towards understanding global eukaryotic biodiversity. Trends Ecol. Evol. 27(4):233-243.

BLANCHET, F.G., CAZELLES, K. \& GRAVEL, D. 2020. Co-occurrence is not evidence of ecological interactions. Ecol. Lett. 23(7):1050-1063.

BLAXTER, M., MANN, J., CHAPMAN, T., THOMAS, F., WHITTON, C., FLOYD, R. \& ABEBE, E. 2005. Defining operational taxonomic units using DNA barcode data. (September):1935-1943.

BLAXTER, M.L. 2004. The promise of a DNA taxonomy. Philos. Trans. R. Soc. B Biol. Sci. 359(1444):669-679.

BOHLMAN, A.S., LAURANCE, F.W., LAURANCE, G.N.S., ASCIMENTO, E.M.H., FEARNSIDE, M.P. \& ANDRADE, A. 2008. Importance of soils, topography and geographic distance in structuring central Amazonian tree communities. J. Veg. Sci. 19(6):863-874.

BURKI, F. 2014. The eukaryotic tree of life from a global phylogenomic perspective. Cold Spring Harb. Perspect. Biol. 6(5):

CALLAHAN, B.J., MCMURDIE, P.J. \& HOLMES, S.P. 2017. Exact sequence variants should replace operational taxonomic units in marker-gene data analysis. ISME J. 11(12):2639-2643.

CAMERON, E.K. et al. 2018. Global gaps in soil biodiversity data. Nat. Ecol. Evol. 2(7):1042-1043

CARNEIRO, L., BRAVO, G.A., ARISTIZÁBAL, N., CUERVO, A.M. \& ALEIXO, A. 2018. Molecular systematics and biogeography of lowland antpittas (Aves, Grallariidae): The role of vicariance and dispersal in the diversification of a widespread Neotropical lineage. Mol. Phylogenet. Evol. 120(November 2017):375-389.

COISSAC, E., PETER, M., HOLLINGSWORTH, S.L. \& TABERLET, P. 2016 From barcodes to genomes: extending the concept of DNA barcoding. Mol. Ecol. 25(7):1423-1428.

COMPSON, Z.G., MCCLENAGHAN, B., SINGER, G.A.C., FAHNER, N.A. \& HAJIBABAEI, M. 2020. Metabarcoding from microbes to mammals: comprehensive bioassessment on a global scale. Front. Ecol. Evol. 8581835 doi $10.3389 /$ fevo.

CONDIT, R., HUBBELL, S.P., LAFRANKIE, J. V, SUKUMAR, R., MANOKARAN, N., FOSTER, R.B. \& ASHTON, P.S. 1996. Species-area and species-individual relationships for tropical trees: a comparison of three 50-ha plots. J. Ecol. 549-562.

CONDIT, R., PITMAN, N., LEIGH, E.G., CHAVE, J., TERBORGH, J., FOSTER, R.B., NÚNEZ, P., AGUILAR, S., VALENCIA, R. \& VILLA, G. 2002. Betadiversity in tropical forest trees. Science (80-. ). 295(5555):666-669.

CONNELL, J.H. 1971. On the role of natural enemies in preventing competitive exclusion in some marine animals and in rain forest trees. In Dynamics of populations (P. J. Den Boer \& G. R. Gradwell, eds) Wageningen, The Netherlands, Wageningen, p.298-392.

COSTA, L.P., LEITE, Y.L.R., DA FONSECA, G.A.B. \& DA FONSECA, M.T. 2000. Biogeography of South American forest mammals: endemism and diversity in the Atlantic Forest 1. Biotropica 32(4b):872-881.

COUTINHO, L.M. 1978. O conceito do cerrado. Rev. Bras. Botânica.

CRACRAFT, J. 1985. Historical biogeography and patterns of differentiation within the South American avifauna: areas of endemism. Ornithol. Monogr 49-84.

CREER, S., FONSECA, V.G., PORAZINSKA, D.L., GIBLIN-DAVIS, R.M., SUNG, W., POWER, D.M., PACKER, M., CARVALHO, G.R., BLAXTER, M.L., LAMBSHEAD, P.J.D. \& THOMAS, W.K. 2010. Ultrasequencing of the meiofaunal biosphere: Practice, pitfalls and promises. Mol. Ecol 19(SUPPL. 1):4-20.

CRISTESCU, M.E. 2019. Can Environmental RNA Revolutionize Biodiversity Science? Trends Ecol. Evol. xx(xx):1-4.

CUVELIER, M.L. et al. 2010. Targeted metagenomics and ecology of globally important uncultured eukaryotic phytoplankton. Proc. Natl. Acad. Sci 107(33):14679-14684.

DEINER, K., BIK, H.M., MÄCHLER, E., SEYMOUR, M., LACOURSIÈREROUSSEL, A., ALTERMATT, F., CREER, S., BISTA, I., LODGE, D.M. \& DE VERE, N. 2017. Environmental DNA metabarcoding: Transforming how we survey animal and plant communities. Mol. Ecol. 26(21):5872-5895. 
DELGADO-BAQUERIZO, M., OLIVERIO, A.M., BREWER, T.E., BENAVENT-GONZÁLEZ, A., ELDRIDGE, D.J., BARDGETT, R.D., MAESTRE, F.T., SINGH, B.K. \& FIERER, N. 2018. A global atlas of the dominant bacteria found in soil. Science (80-. ). 359(6373):320-325.

DINERSTEIN, E., OLSON, D., JOSHI, A., VYNNE, C., BURGESS, N.D., WIKRAMANAYAKE, E., HAHN, N., PALMINTERI, S., HEDAO, P. \& NOSS, R. 2017. An ecoregion-based approach to protecting half the terrestrial realm. Bioscience 67(6):534-545.

DOLIWA, A., DUNTHORN, M., RASSOSHANSKA, E., MAHÉ, F., BASS, D. \& RITTER, C.D. 2020. Identifying potential hosts of short-branch Microsporidia. Microb. Ecol. 1-5.

DRAKARE, S., LENNON, J.J. \& HILLEBRAND, H. 2006. The imprint of the geographical, evolutionary and ecological context on species-area relationships. Ecol. Lett. 9(2):215-227.

ESQUIVEL-MUELBERT, A., GALBRAITH, D., DEXTER, K.G., BAKER, T.R., LEWIS, S.L., MEIR, P., ROWLAND, L., DA COSTA, A.C.L., NEPSTAD, D. \& PHILLIPS, O.L. 2017. Biogeographic distributions of neotropical trees reflect their directly measured drought tolerances. Sci. Rep. 7(1):1-11.

FERNANDES, N.M., CAMPELLO-NUNES, P.H., PAIVA, T.S., SOARES, C.A.G. \& SILVA-NETO, I.D. 2021. Ciliate Diversity From Aquatic Environments in the Brazilian Atlantic Forest as Revealed by HighThroughput DNA Sequencing. Microb. Ecol. 81(3):630-643.

FILKER, S., FORSTER, D., WEINISCH, L., MORA-RUIZ, M., GONZÁLEZ, B., FARÍAS, M.E., ROSSELLÓ-MÓRA, R. \& STOECK, T. 2017. Transition boundaries for protistan species turnover in hypersaline waters of different biogeographic regions. Environ. Microbiol. 19(8):3186-3200.

FILKER, S., SOMMARUGA, R., VILA, I. \& STOECK, T. 2016. Microbial eukaryote plankton communities of high-mountain lakes from three continents exhibit strong biogeographic patterns. Mol. Ecol. 25(10):2286-2301.

FINLAY, B.J. 2002. Global dispersal of free-living microbial eukaryote species. Science (80-. ). 296(5570):1061-1063.

FINLAY, B.J. \& FENCHEL, T. o. m. 2005. Cosmopolitan Metapopulations of Free-Living Microbial Eukaryotes. Supplementary Information. Protist 155(2):e1-e38.

FOISSNER, W. 2006. Biogeography and dispersal of micro-organisms: A review emphasizing protists. Acta Protozool. 45(2):111-136.

FRECKLETON, R.P. \& LEWIS, O.T. 2006. Pathogens, density dependence and the coexistence of tropical trees. Proc. R. Soc. B Biol. Sci. 273(1604):2909-2916.

FUKAMI, T., BEAUMONT, H.J.E., ZHANG, X.X. \& RAINEY, P.B. 2007. Immigration history controls diversification in experimental adaptive radiation. Nature 446(7134):436-439.

FUKAMI, T. \& MORIN, P.J. 2003. Productivity-biodiversity relationships depend on the history of community assembly. Nature 424(6947):423-426.

FURLEY, P.A. 1999. The nature and diversity of neotropical savanna vegetation with particular reference to the Brazilian cerrados. Glob. Ecol. Biogeogr. $8(3-4): 223-241$.

GEISEN, S., FIORE-DONNO, A.M., WALOCHNIK, J. \& BONKOWSKI, M. 2014. Acanthamoeba everywhere: high diversity of Acanthamoeba in soils. Parasitol. Res. 113(9):3151-3158.

GEISEN, S., MITCHELL, E.A.D., ADL, S., BONKOWSKI, M., DUNTHORN, M., EKELUND, F., FERNÁNDEZ, L.D., JOUSSET, A., KRASHEVSKA, V., SINGER, D., SPIEGEL, F.W., WALOCHNIK, J. \& LARA, E. 2018. Soil protists: A fertile frontier in soil biology research. FEMS Microbiol. Rev. 42(3):293-323.

GEISEN, S., TVEIT, A.T., CLARK, I.M., RICHTER, A., SVENNING, M.M., BONKOWSKI, M. \& URICH, T. 2015. Metatranscriptomic census of active protists in soils. ISME J. 9(10):2178-2190.

GEISEN, S., VAULOT, D., MAHÉ, F., LARA, E., DE VARGAS, C. \& BASS, D. 2019. A user guide to environmental protistology: primers, metabarcoding, sequencing, and analyses. BioRxiv 850610.

GIEBNER, H., LANGEN, K., BOURLAT, S.J., KUKOWKA, S., MAYER, C., ASTRIN, J.J., MISOF, B. \& FONSECA, V.G. 2020. Comparing diversity levels in environmental samples: DNA sequence capture and metabarcoding approaches using $18 \mathrm{~S}$ and COI genes. Mol. Ecol. Resour.
HAND, B.K., LOWE, W.H., KOVACH, R.P., MUHLFELD, C.C. \& LUIKART, G. 2015. Landscape community genomics: Understanding eco-evolutionary processes in complex environments. Trends Ecol. Evol. 30(3):161-168.

HAUGAASEN, T. \& PERES, C.A. 2006. Floristic, edaphic and structural characteristics of flooded and unflooded forests in the lower Rio Purús region of central Amazonia, Brazil. Acta Amaz. 36(1):25-35.

HECTOR, A., SCHMID, B., BEIERKUHNLEIN, C., CALDEIRA, M.C., DIEMER, M., DIMITRAKOPOULOS, P.G., FINN, J.A., FREITAS, H., GILLER, P.S. \& GOOD, J. 1999. Plant diversity and productivity experiments in European grasslands. Science (80-. ). 286(5442):1123-1127.

HILLEBRAND, H. \& AZOVSKY, A.I. 2001. Body size determines the strength of the latitudinal diversity gradient. 3(August 2000):251-256.

HOOPER, D.U., CHAPIN III, F.S., EWEL, J.J., HECTOR, A., INCHAUSTI, P., LAVOREL, S., LAWTON, J.H., LODGE, D.M., LOREAU, M. \& NAEEM, S. 2005. Effects of biodiversity on ecosystem functioning: a consensus of current knowledge. Ecol. Monogr. 75(1):3-35.

HOORN, C., WESSELINGH, F.P., STEEGE, H., BERMUDEZ, M.A., MORA, A., SEVINK, J., SANMARTÍN, I., ANDERSON, C.L., FIGUEIREDO, J.P., JARAMILLO, C., RIFF, D., NEGRI, F.R., HOOGHIEMSTRA, H., LUNDBERG, J., STADLER, T., SÄRKINEN, T. \& ANTONELLI, A. 2010. Amazonia through time: Andean uplift, climate change, landscape evolution, and biodiversity. Science (80-. ). 330(November):927-931.

HUGHES, C.E., PENNINGTON, R.T. \& ANTONELLI, A. 2012. Neotropical plant evolution: assembling the big picture. Bot. J. Linn. Soc. 171(1):1-18.

JAMY, M., FOSTER, R., BARBERA, P., CZECH, L., KOZLOV, A., STAMATAKIS, A., BENDING, G., HILTON, S., BASS, D. \& BURKI, F. 2020. Long-read metabarcoding of the eukaryotic rDNA operon to phylogenetically and taxonomically resolve environmental diversity. Mol. Ecol. Resour. 20(2):429-443.

JANZEN, D.H. 1970. Herbivores and the number of tree species in tropical forests. Am. Nat. 104(940):501-528.

KEELING, P.J., BURGER, G., DURNFORD, D.G., LANG, B.F., LEE, R.W., PEARLMAN, R.E., ROGER, A.J. \& GRAY, M.W. 2005. The tree of eukaryotes. Trends Ecol. Evol. 20(12):670-676.

LAFFERTY, K.D. \& KURIS, A.M. 2002. Trophic strategies , animal diversity and body size. 17(11):507-513.

LANSAC-TÔHA, F.A., VELHO, L.F.M., COSTA, D.M., SIMÕES, N.R. \& ALVES, G.M. 2014. Structure of the testate amoebae community in different habitats in a neotropical floodplain. Braz. J. Biol. 74(1):181-90.

LENTENDU, G., BUOSI, P.R.B., CABRAL, A.F., TREVIZAN SEGÓVIA, B., RAMOS MEIRA, B., LANSAC-TÔHA, F.M., VELHO, L.F.M., RITTER, C.D. \& DUNTHORN, M. 2018. Protist Biodiversity and Biogeography in Lakes From Four Brazilian River-Floodplain Systems. J. Eukaryot. Microbiol.

LENTENDU, G., MAHÉ, F., BASS, D., RUECKERT, S., STOECK, T. \& DUNTHORN, M. 2018. Consistent patterns of high alpha and low beta diversity in tropical parasitic and free-living protists. Mol. Ecol. 27(13):2846-2857.

LI, N., CHU, H., QI, Y., LI, C., PING, X., SUN, Y. \& JIANG, Z. 2019. Alpha and beta diversity of birds along elevational vegetation zones on the southern slope of Altai Mountains: Implication for conservation. Glob. Ecol. Conserv. 19e00643.

LOCEY, K.J. \& LENNON, J.T. 2016. Scaling laws predict global microbial diversity. Proc. Natl. Acad. Sci. 113(21):5970-5975.

LOGARES, R., DEUTSCHMANN, I.M., JUNGER, P.C., GINER, C.R., KRABBERØD, A.K., SCHMIDT, T.S.B., RUBINAT-RIPOLL, L., MESTRE, M., SALAZAR, G. \& RUIZ-GONZÁLEZ, C. 2020. Disentangling the mechanisms shaping the surface ocean microbiota. Microbiome 81-17.

LOGARES, R., TESSON, S.V.M., CANBÄCK, B., PONTARP, M., HEDLUND, K. \& RENGEFORS, K. 2018. Contrasting prevalence of selection and drift in the community structuring of bacteria and microbial eukaryotes. Environ. Microbiol. 20(6):2231-2240.

LOVEJOY, N.R., ALBERT, J.S. \& CRAMPTON, W.G.R. 2006. Miocene marine incursions and marine/freshwater transitions: Evidence from Neotropical fishes. J. South Am. Earth Sci. 21(1-2):5-13. 
MAHÉ, F. et al. 2017. Parasites dominate hyperdiverse soil protist communities in Neotropical rainforests. Nat. Ecol. Evol. 1(4):1-8.

MARES, M.A. \& ERNEST, K.A. 2019. Population and community ecology of small mammals in a gallery forest of central Brazil. J. Mammal. 76(3):750-768.

MARTINY, J.B.H., BOHANNAN, B.J.M., BROWN, J.H., COLWELL, R.K., FUHRMAN, J.A., GREEN, J.L., HORNER-DEVINE, M.C., KANE, M., KRUMINS, J.A. \& KUSKE, C.R. 2006. Microbial biogeography: putting microorganisms on the map. Nat. Rev. Microbiol. 4(2):102-112.

MATEO, R.G., FELICÍSIMO, Á.M., POTTIER, J., GUISAN, A. \& MUÑOZ, J. 2012. Do stacked species distribution models reflect altitudinal diversity patterns? PLoS One 7(3):e32586.

MENG, H., LI, K., NIE, M., WAN, J.-R., QUAN, Z.-X., FANG, C.-M., CHEN, J.K., GU, J.-D. \& LI, B. 2013. Responses of bacterial and fungal communities to an elevation gradient in a subtropical montane forest of China. Appl. Microbiol. Biotechnol. 97(5):2219-2230.

MIKHAILOV, I.S., ZAKHAROVA, Y.R., BUKIN, Y.S., GALACHYANTS, Y.P., PETROVA, D.P., SAKIRKO, M. V \& LIKHOSHWAY, Y. V. 2019. Co-occurrence networks among bacteria and microbial eukaryotes of Lake Baikal during a spring phytoplankton bloom. Microb. Ecol. 77(1):96-109.

MORLON, H., CHUYONG, G., CONDIT, R., HUBBELL, S., KENFACK, D., THOMAS, D., VALENCIA, R. \& GREEN, J.L. 2008. A general framework for the distance-decay of similarity in ecological communities. Ecol. Lett. 11(9):904-917.

MORRONE, J.J. 2014. Cladistic biogeography of the Neotropical region: identifying the main events in the diversification of the terrestrial biota. Cladistics 30(2):202-214.

MYERS, N., MITTERMEIER, R.., MITTERMEIER, C.., DA FONSECA, G.A. \& KENT, J. 2000. Biodiversity hotspots for conservation priorities. Nature 403: 853(February):853-858.

MYSTER, R.W. 2016. The physical structure of forests in the Amazon Basin: a review. Bot. Rev. 82(4):407-427.

NEGREIROS, O.P., SEGOVIA, B.T., LANSAC-TÔHA, F.M., MEIRA, B.R. de, BUOSI, P.R.B., CABRAL, A.F., SILVA, H.S., LANSAC-TÔHA, F.A. \& VELHO, L.F.M. 2017. Structure and dynamic of planktonic ciliate community in a large Neotropical river: the relevance of the pluviosity and tributaries in the biodiversity maintenance. Acta Limnol. Bras. 29(0):

NOGUEIRA, C., COLLI, G.R. \& MARTINS, M. 2009. Local richness and distribution of the lizard fauna in natural habitat mosaics of the Brazilian Cerrado. 83-96.

NOLTE, V., PANDEY, R.V., JOST, S., MEDINGER, R., OTTENWAELDER, B., BOENIGK, J. \& SCHLOETTERER, C. 2010. Contrasting seasonal niche separation between rare and abundant taxa conceals the extent of protist diversity. Mol. Ecol. 19(14):2908-2915.

NOVOTNY, V., DROZD, P., MILLER, S.E., KULFAN, M., JANDA, M., BASSET, Y. \& WEIBLEN, G.D. 2006. Why are there so many species of herbivorous insects in tropical rainforests? Science (80-. ). 313(5790):1115-1118.

O’MALLEY, M.A. \& DUPRÉ, J. 2007. Size doesn't matter: Towards a more inclusive philosophy of biology.

OLIVERIO, A.M., GEISEN, S., DELGADO-BAQUERIZO, M., MAESTRE, F.T., TURNER, B.L. \& FIERER, N. 2020. The global-scale distributions of soil protists and their contributions to belowground systems. (January):1-11.

OLSON, D.M., DINERSTEIN, E., WIKRAMANAYAKE, E.D., BURGESS, N.D., POWELL, G.V.N., UNDERWOOD, E.C., D'AMICO, J.A., ITOUA, I., STRAND, H.E. \& MORRISON, J.C. 2001. Terrestrial Ecoregions of the World: A New Map of Life on EarthA new global map of terrestrial ecoregions provides an innovative tool for conserving biodiversity. Bioscience 51(11):933-938.

PEAY, K.G., VON SPERBER, C., CARDARELLI, E., TOJU, H., FRANCIS, C.A., CHADWICK, O.A. \& VITOUSEK, P.M. 2017. Convergence and contrast in the community structure of Bacteria, Fungi and Archaea along a tropical elevation-climate gradient. FEMS Microbiol. Ecol. 93(5):.

PETERSEN, H. \& LUXTON, M. 1986. A Comparative Analysis of Soil Fauna Populations and Their Role in Decomposition Processes. Oikos 39(3):288.
PLOTKIN, J.B., POTTS, M.D., DOUGLAS, W.Y., BUNYAVEJCHEWIN, S., CONDIT, R., FOSTER, R., HUBBELl, S., LAFRANKIE, J., MANOKARAN, N. \& SENG, L.H. 2000. Predicting species diversity in tropical forests. Proc. Natl. Acad. Sci. 97(20):10850-10854.

PORAZINSKA, D.L., GIBLIN-DAVIS, R.M., FALLER, L., FARMERIE, W., KANZAKI, N., MORRIS, K., POWERS, T.O., TUCKER, A.E., SUNG, W.A.Y. \& THOMAS, W.K. 2009. Evaluating high-throughput sequencing as a method for metagenomic analysis of nematode diversity. Mol. Ecol. Resour. 9(6):1439-1450.

RIBAS, C.C., ALEIXO, A., NOGUEIRA, A.C.R., MIYAKI, C.Y. \& CRACRAFT, J. 2012. A palaeobiogeographic model for biotic diversification within Amazonia over the past three million years. Proc. R. Soc. B Biol. Sci. 279(1729):681-689.

RICKLEFS, R.E. 2008. The economy of nature. 6 ed. Macmillan, New York.

RITTER, C.D., DUNTHORN, M., ANSLAN, S., XAVIER, V., TEDERSOO, L., HENRIK, R. \& ANTONELLI, A. 2020. Advancing biodiversity assessments with environmental DNA : Long-read technologies help reveal the drivers of Amazonian fungal diversity. 001-16.

RITTER, C.D., FAURBY, S., BENNETT, D.J., NAKA, L.N., TER STEEGE, H., ZIZKA, A., HAENEL, Q., NILSSON, R.H. \& ANTONELLI, A. 2019. The pitfalls of biodiversity proxies: Differences in richness patterns of birds, trees and understudied diversity across Amazonia. Sci. Rep. 9(1):1-13.

RITTER, C.D., FORSTER, D., AZEVEDO, J.A.R., ANTONELli, A., NILSSON, R.H., TRUJILLO, M.E. \& DUNTHORN, M. 2021. Assessing Biotic and Abiotic Interactions of Microorganisms in Amazonia through Co-Occurrence Networks and DNA Metabarcoding. Microb. Ecol. 1-15.

RITTER, C.D., HÄGGQVIST, S., KARLSSON, D., SÄÄKSJÄRVI, I.E., MUASYA, A.M., NILSSON, R.H. \& ANTONELLI, A. 2019. Biodiversity assessments in the 21 st century: The potential of insect traps to complement environmental samples for estimating eukaryotic and prokaryotic diversity using high-throughput DNA metabarcoding. Genome 62(3):.

RITTER, C.D., ZIZKA, A., BARNES, C., NILSSON, R.H., ROGER, F. \& ANTONELLI, A. 2019. Locality or habitat? Exploring predictors of biodiversity in Amazonia. Ecography (Cop.). 42(2):321-333.

RITTER, C.D., ZIZKA, A., ROGER, F., TUOMISTO, H., BARNES, C., NILSSON, R.H. \& ANTONELLI, A. 2018. High-throughput metabarcoding reveals the effect of physicochemical soil properties on soil and litter biodiversity and community turnover across Amazonia. PeerJ 2018(9):e5661.

RUECKERT, S., PIPALIYA, S. V \& DACKS, J.B. 2019. Evolution: parallel paths to parasitism in the apicomplexa. Curr. Biol. 29(17):R836-R839.

RYŠÁNEK, D., HRČKOVÁ, K. \& ŠKALOUD, P. 2015. Global ubiquity and local endemism of free-living terrestrial protists: phylogeographic assessment of the streptophyte alga K lebsormidium. Environ. Microbiol. 17(3):689-698.

SANTOFERRARA, L., BURKI, F., FILKER, S., LOGARES, R., DUNTHORN, M. \& MCMANUS, G.B. 2020. Perspectives from Ten Years of Protist Studies by High-Throughput Metabarcoding. J. Eukaryot. Microbiol.

SCHNITZER, S.A., KLIRONOMOS, J.N., HILLERISLAMBERS, J., KINKEL, L.L., REICH, P.B., XIAO, K., RILLIG, M.C., SIKES, B.A., CALLAWAY, R.M., MANGAN, S.A., VAN NES, E.H. \& SCHEFFER, M. 2011. Soil microbes drive the classic plant diversity-productivity pattern. Ecology 92(2):296-303.

SHEN, C., GUNINA, A., LUO, Y., WANG, J., HE, J., KUZYAKOV, Y., HEMP, A., CLASSEN, A.T. \& GE, Y. 2020. Contrasting patterns and drivers of soil bacterial and fungal diversity across a mountain gradient. Environ. Microbiol. 22(8):3287-3301.

SHERR, E.B. \& SHERR, B.F. 2002. Significance of predation by protists in aquatic microbial food webs. Antonie Van Leeuwenhoek. 81293-308.

SHOKRALLA, S., GIBSON, J.F., KING, I., BAIRD, D.J., JANZEN, D.H., HALLWACHS, W. \& HAJIBABAEI, M. 2016. Environmental DNA barcode sequence capture: targeted, PCR-free sequence capture for biodiversity analysis from bulk environmental samples. BioRxiv 087437.

SILES, J.A. \& MARGESIN, R. 2016. Abundance and diversity of bacterial, archaeal, and fungal communities along an altitudinal gradient in alpine forest soils: what are the driving factors? Microb. Ecol. 72(1):207-220. 
SILVA, J.L. da \& VAZ-DE-MELLO, F.Z. 2020. Areas of endemism in the Brazilian Atlantic Forest based on the distribution of dung beetles (Coleoptera, Scarabaeidae, Scarabaeinae). Iheringia. Série Zool. 110.

DA SILVA, J.M.C. \& BATES, J.M. 2002. Biogeographic Patterns and Conservation in the South American Cerrado : A Tropical Savanna Hotspot. Bioscience 52(3):225-233.

SILVA, S.M., PETERSON, A.T., CARNEIRO, L., BURLAMAQUI, T.C.T., RIBAS, C.C., SOUSA-NEVES, T., MIRANDA, L.S., FERNANDES, A.M., D'HORTA, F.M. \& ARAÚJO-SILVA, L.E. 2019. A dynamic continental moisture gradient drove Amazonian bird diversification. Sci. Adv. 5(7):eaat5752.

SIMÃO, T.L.L., BORGES, A.G., GANO, K.A., DAVIS-RICHARDSON, A.G., BROWN, C.T., FAGEN, J.R., TRIPLETT, E.W., DIAS, R., MONDIN, C.A., DA SILVA, R.M., EIZIRIK, E. \& UTZ, L.R.P. 2017. Characterization of ciliate diversity in bromeliad tank waters from the Brazilian Atlantic Forest. Eur. J. Protistol. 61359-365.

SINGER, D., MITCHELL, E.A.D., PAYNE, R.J., BLANDENIER, Q., DUCKERT, C., FERNÁNDEZ, L.D., FOURNIER, B., HERNÁNDEZ, C.E., GRANATH, G. \& RYDIN, H. 2019. Dispersal limitations and historical factors determine the biogeography of specialized terrestrial protists. Mol. Ecol. 28(12):3089-3100.

SINGER, D., SEPPEY, C.V.W., LENTENDU, G., DUNTHORN, M., BASS, D., BELBAHRI, L., BLANDENIER, Q., DEBROAS, D., DE GROOT, G.A. \& DE VARGAS, C. 2021. Protist taxonomic and functional diversity in soil, freshwater and marine ecosystems. Environ. Int. 146106262.

SOININEN, J., MCDONALD, R. \& HILLEBRAND, H. 2007. The distance decay of similarity in ecological communities. Ecography (Cop.). 30(1):3-12.

TER STEEGE, H. \& HAMMOND, D.S. 2001. Character convergence, diversity, and disturbance in tropical rain forest in Guyana. Ecology 82(11):3197-3212.

TER STEEGE, H., PITMAN, N.C.A., PHILLIPS, O.L., CHAVE, J., SABATIER, D., DUQUE, A., MOLINO, J.-F., PRÉVOST, M.-F., SPICHIGER, R. \& CASTELLANOS, H. 2006. Continental-scale patterns of canopy tree composition and function across Amazonia. Nature 443(7110):444.

TER STEEGE, H.T., PITMAN, N., SABATIER, D., CASTELLANOS, H., HOUT, P., DALY, D.C., SILVEIRA, M., PHILLIPS, O., VASQUEZ, R., ANDEL, T.V. \& DUIVENVOORDEN, J. 2003. A spatial model of tree alpha-diversity and tree density for the Amazon. Biodivers. Conserv. 122255-2277.

STEELE, J.A., COUNTWAY, P.D., XIA, L., VIGIL, P.D., BEMAN, J.M., KIM, D.Y., CHOW, C.E.T., SACHDEVA, R., JONES, A.C., SCHWALBACH, M.S., ROSE, J.M., HEWSON, I., PATEL, A., SUN, F., CARON, D.A. \& FUHRMAN, J.A. 2011. Marine bacterial, archaeal and protistan association networks reveal ecological linkages. ISME J. 5(9):1414-1425.

STEFAN, G., CORNELIA, B., JÖRG, R. \& MICHAEL, B. 2014. Soil water availability strongly alters the community composition of soil protists. Pedobiologia (Jena). 57(4-6):205-213.

STEHLI, F.G. \& WEBB, S.D. 2013. The great American biotic interchange. Springer Science \& Business Media.
SUTHERLAND, W.J., FRECKLETON, R.P., GODFRAY, H.C.J., BEISSINGER, S.R., BENTON, T., CAMERON, D.D., CARMEL, Y., COOMES, D.A., COULSON, T. \& EMMERSON, M.C. 2013. Identification of 100 fundamental ecological questions. J. Ecol. 101(1):58-67.

TABERLET, P., BONIN, A., COISSAC, E. \& ZINGER, L. 2018. Environmental DNA: For biodiversity research and monitoring. Oxford University Press.

TEDERSOO, L. et al. 2014. Global diversity and geography of soil fungi. Science 346(6213):1052-3.

THOMPSON, J.F. \& MILOS, P.M. 2011. The properties and applications of single-molecule DNA sequencing. Genome Biol. 12(2):217.

TUOMISTO, H., RUOKOLAINEN, K., VORMISTO, J., DUQUE, A., SÁNCHEZ, M., PAREDES, V.V. \& LÄHTEENOJA, O. 2017. Effect of sampling grain on patterns of species richness and turnover in Amazonian forests. Ecography (Cop.). 40(7):840-852.

DE VARGAS, C., AUDIC, S., HENRY, N., DECELLE, J., MAHÉ, F., LOGARES, R., LARA, E., BERNEY, C., LE BESCOT, N. \& PROBERT, I. 2015. Eukaryotic plankton diversity in the sunlit ocean. Science (80-. ). 348(6237):.

VEINTIMILLA, D., NGO BIENG, M.A., DELGADO, D., VILCHEZMENDOZA, S., ZAMORA, N. \& FINEGAN, B. 2019. Drivers of tropical rainforest composition and alpha diversity patterns over a 2,520 $\mathrm{m}$ altitudinal gradient. Ecol. Evol. 9(10):5720-5730.

VILLAMARÍN, C., RIERADEVALL, M. \& PRAT, N. 2020. Macroinvertebrate diversity patterns in tropical highland Andean rivers. Limnetica 39(2):677-691.

WEISSE, T. 2017. Functional diversity of aquatic ciliates. Eur. J. Protistol. 61331-358

DE WIT, R. \& BOUVIER, T. 2006. 'Everything is everywhere, but, the environment selects'; what did Baas Becking and Beijerinck really say? Environ. Microbiol. 8(4):755-758.

WOODWARD, G., EBENMAN, B., EMMERSON, M., MONTOYA, J.M., OLESEN, J.M., VALIDO, A. \& WARREN, P.H. 2005. Body size in ecological networks. 20(7):

WORDEN, A.Z., FOLLOWS, M.J., GIOVANNONI, S.J., WILKEN, S., ZIMMERMAN, A.E. \& KEELING, P.J. 2015. Rethinking the marine carbon cycle: factoring in the multifarious lifestyles of microbes. Science (80-. ). 347(6223):

ZINGER, L. et al. 2019. Body size determines soil community assembly in a tropical forest. Mol. Ecol. 28(3):528-543.

ZINGER, L., BONIN, A., ALSOS, I.G., BÁLINT, M., BIK, H., BOYER, F., CHARITON, A.A., CREER, S., COISSAC, E. \& DEAGLE, B.E. 2019. DNA metabarcoding - Need for robust experimental designs to draw sound ecological conclusions. Mol. Ecol. 28(8):1857-1862.

ZINGER, L., DONALD, J., BROSSE, S., GONZALEZ, M.A., IRIBAR, A., LEROY, C. \& MARTINS LOPES, C. 2020. Advances and prospects of environmental DNA in neotropical rainforests. Adv. Ecol. Res. 62331-373.

ZIZKA, A., STEEGE, H. ter, PESSOA, M. do C.R. \& ANTONELLI, A. 2018. Finding needles in the haystack: where to look for rare species in the American tropics. Ecography (Cop.). 41(2):321-330.

Received: 19/03/2021

Accepted: 10/08/2021

Published online: $25 / 10 / 2021$ 